\title{
ANALISIS FAKTOR-FAKTOR YANG MEMPENGARUHI EFISIENSI KERJA KARYAWAN PADA PT. PETRO FAJAR BERLIAN, MEDAN
}

\author{
Oleh : \\ Syaifuddin \\ Dosen dpk. Universitas Quality, Medan
}

\begin{abstract}
Abstraksi
Tujuan penelitian ini adalah untuk mengetahui dan menganalisis faktor apa yang paling dominan mempengaruhi efisiensi kerja karyawan pada PT. Petro Fajar Berlian, Medan. Penelitian ini dilaksanakan pada PT. Petro Fajar Berlian yang berlamat di Kompleks Villa Asoka Blok C No. 6, Medan. Penelitian ini dilakukan pada bulan Mei 2016. Untuk analisis faktor, ukuran sampel yang direkomendasikan adalah tidak kurang dari 60 responden. Sebagai aturan umum, beberapa peneliti merekomendasikan 5:1, 10:1, dan 20:1 responden untuk setiap variabel. Penelitian ini menggunakan 14 variabel maka yang menjadi sampel penelitian adalah $5 \times 14=70$ orang. Variabel yang akan diteliti adalah faktor-faktor yang mempengaruhi efisiensi kerja karyawan yaitu : Kemampuan fisik $\left(\mathrm{X}_{1}\right)$, Pendidikan dan pelatihan (diklat) $\left(\mathrm{X}_{2}\right)$, Pengalaman kerja $\left(\mathrm{X}_{3}\right)$, Kesejahtraan $\left(\mathrm{X}_{4}\right)$, Syarat kerja $\left(\mathrm{X}_{5}\right)$, Lingkungan kerja $\left(\mathrm{X}_{6}\right)$, Waktu jam kerja $\left(\mathrm{X}_{7}\right)$, Ketaatan $\left(\mathrm{X}_{8}\right)$, Jadwal pekerjaan $\left(\mathrm{X}_{9}\right)$, Pengorganisasian $\left(\mathrm{X}_{10}\right)$, Sarana dan prasarana $\left(\mathrm{X}_{11}\right)$, Kondisi ruangan kerja $\left(\mathrm{X}_{12}\right)$, Penghargaan $\left(\mathrm{X}_{13}\right)$ dan Kepemimpinan $\left(\mathrm{X}_{14}\right)$. Hasil penelitian menunjukkan bahwa faktor yang paling dominan mempengaruhi efisiensi kerja karyawan pada PT. Petro Fajar Berlian, Medan adalah kondisi ruangan kerja dengan nilai korelasi sebesar 0,848. Faktor kedua yang memiliki pengaruh dominan terhadap efisiensi kerja karyawan adalah kesejahteraan karyawan dengan nilai korelasi 0,842. Faktor ketiga yang memiliki pengaruh dominan terhadap efisiensi kerja karyawan adalah kemampuan fisik karyawan dengan nilai korelasi 0,798. Dari hasil pengujian faktor dapat disimpulkan bahwa pada faktor 1 bernilai 0,502; faktor 2 bernilai 0,477, faktor 3 bernilai 0,579, faktor 4 bernilai 0,572 dan faktor 5 bernilai 0,399. Kelima faktor yang terbentuk sudah tepat karena mempunyai nilai korelasi yang cukup tinggi. Dengan demikian, antara faktor cenderung terjadi interkorelasi.
\end{abstract}

Kata kunci : efisiensi kerja dan karyawan

\section{Abstract}

The purpose of this research was to determine and analyze what factors are the most dominant influence the efficiency of employees at PT. Petro Fajar Berlian, Medan. This research was conducted at PT. Petro Fajar Berlian is located at Villa Asoka Block C No. 6, Medan. This research was conducted in May 2016. For the factor analysis, the recommended sample size is not less than 60 respondents. As a general rule, some researchers recommend 5: 1, 10: 1 and 20: 1 respondents for each variable. This research uses 14 variables that were selected as sample is $5 \times 14=70$. Variables to be studied are the factors that affect the efficiency of employees, namely: physical ability (X1), education and training (X2), Work experience (X3), Welfare (X4), Terms of employment (X5), work environment (X6), time business hours (X7), Obedience (X8), schedule jobs (X9), organization (X10), facilities and infrastructure (X11), Condition of workspace (X12), Appreciation (X13) and Leadership (X14). The results showed that the most dominant factor affecting the efficiency of employees at PT. Petro Fajar Berlian, Medan is the condition of workspace with the correlation value of 0.848. The second factor that has a dominant influence on employee efficiency is the welfare of the employees with a 0.842 correlation value. The third factor which has a dominant influence on employee efficiency is the physical abilities of employees with a 0.798 correlation value. From the test results can be concluded that factors in factor 1 is worth 0.502; factor 2 is worth 0.477, factor 3 is worth 0,579, factor 4 is worth 0.572 and factor 5 is worth 0.399 . The five factors that form was appropriate because it has a fairly high correlation value. Thus, among the factors likely to occur intercorrelation.

Keywords: work efficiency and employees

\section{A. PENDAHUluan}

\section{Latar Belakang Masalah}

Sumber daya manusia merupakan salah satu faktor penting dalam suatu organisasi. Oleh karena itu, sumber daya manusia harus dikelola dengan baik untuk meningkatkan efektifitas dan efisien organisasi. Sumber daya manusia sebagai kekuatan yang bersumber dari potensi pegawai dimiliki organisasi untuk mencapai tujuannya.
Sumber daya organisasi dibedakan dalam 2 kelompok, yaitu sumber daya manusia dan sumber daya non manusia. Sumber daya manusia merupakan semua orang yang berstatus sebagai anggota dalam organisasi yang masing-masing memiliki peran dan fungsi. Sumber daya manusia terdiri dari atas sumber daya alam, modal, mesin, teknologi, material dan lain-lain. Kedua kategori sumber daya tersebut sama-sama memiliki peran penting, tetapi sumber daya manusia merupakan 
faktor dominan karena satu-satunya sumber daya yang memiliki akal, perasaan, keinginan, karsa, kebutuhan, pengetahuan, keterampilan, motivasi dan karya yang dapat dikelola oleh organisasi untuk mencapai tujuannya.

Pada umumnya orang berkecimpung dalam manajemen sumber daya manusia berpendapat bahwa efisiensi menunjukkan kemampuan bawahan dalam menyelesaikan tugas-tugasnya. Efisiensi kerja mempengaruhi seberapa banyak pengawai memberikan kontribusi kepada organisasi. Efisiensi kerja karyawan berpengaruh terhadap pencapaian tujuan organisasi yang telah ditetapkan. Oleh sebab itu, manajemen harus melakukan berbagai kegiatan untuk meningkatkan efisiensi karyawan.

Menurut Miraza (2004 : 45) efisiensi adalah pemakaian biaya atau bentuk pengorbanan lainnya dari setiap komponen pada setiap aktivitas usaha yang berjalan secara wajar. Komponen tersebut meliputi biaya, waktu, dan tenaga kerja.

Berdasarkan perbandingan terbaik usaha dalam setiap pekerjaan terutama ditentukan oleh bagaimana pekerjaan itu dilakukan. Jika efisiensi kerja pada umunya merupakan hasil dari cara-cara kerja yang sesuai dengan prosedur kerja.Cara kerja yang efisien adalah cara yang tanpa sedikitpun mengurangi hasil yang hendak dicapai seperti : cara termudah, tercepat, dan terpendek.

Setiap organisasi dalam menjalankan aktifitasnya pasti menghadapi berbagai masalah yang harus diselesaikan. Salah satunya mengenai efisiensi kerja karyawan pada PT. Petro Fajar Berlian, Medan masih adanya hambatan dalam penyelesaian pekerjaan karyawan yang tidak selesai tepat pada waktu yang ditentukan, kemudian tingkat pendidikan karyawan yang kurang, hal ini memungkinkan bahwa pekerjaan yang dibebankan tidak sesuai bidangnya, kedua masalah diatas mengakibatkan efisiensi karyawan menurun atau standar efisiensi yang ditetapkan perusahaan tidak tercapai, sehingga tujuan organisasi akan terkendala.

\section{Rumusan Masalah}

a. Faktor apa yang paling dominan mempengaruhi efisiensi kerja karyawan pada PT. Petro Fajar berlian, Medan?

\section{Tujuan Penelitian}

Tujuan penelitian ini adalah untuk mengetahui dan menganalisis faktor apa yang paling dominan mempengaruhi efisiensi kerja karyawan pada PT. Petro Fajar berlian, Medan.

\section{Metode Penelitian}

Penelitian ini dilaksanakan pada PT. Petro Fajar Berlian yang berlamat di Kompleks Villa Asoka Blok C No. 6, Medan. Penelitian ini dilakukan pada bulan Mei 2016. Untuk analisis faktor, ukuran sampel yang direkomendasikan adalah tidak kurang dari 60 responden. Sebagai aturan umum, beberapa peneliti merekomendasikan 5:1, 10:1, dan 20:1 responden untuk setiap variabel. Penelitian ini menggunakan 14 variabel maka yang menjadi sampel penelitian adalah 5 x $14=70$ orang. Adapun teknik penentuan sampel adalah stratified random sampling yaitu pengambilan anggota sampel dari populasi secara acak sederhana. Operasional variabel merupakan batasan pokok pembahasan yang akan diteliti. Variabel yang akan diteliti adalah faktor-faktor yang mempenggaruhi efisiensi kerja karyawan yaitu : Kemampuan fisik $\left(\mathrm{X}_{1}\right)$, Pendidikan dan pelatihan (diklat) $\left(\mathrm{X}_{2}\right)$, Pengalaman kerja $\left(\mathrm{X}_{3}\right)$, Kesejahtraan $\left(\mathrm{X}_{4}\right)$, Syarat kerja $\left(\mathrm{X}_{5}\right)$, Lingkungan kerja $\left(\mathrm{X}_{6}\right)$, Waktu jam kerja $\left(\mathrm{X}_{7}\right)$, Ketaatan $\left(\mathrm{X}_{8}\right)$, Jadwal pekerjaan $\left(\mathrm{X}_{9}\right)$, Pengorganisasian $\left(\mathrm{X}_{10}\right)$, Sarana dan prasarana $\left(\mathrm{X}_{11}\right)$, Kondisi ruangan kerja $\left(\mathrm{X}_{12}\right)$, Penghargaan $\left(\mathrm{X}_{13}\right)$ dan Kepemimpinan $\left(\mathrm{X}_{14}\right)$.

\section{B. LANDASAN TEORI}

\section{Efisiensi Karyawan}

Efisiensi berkaitan erat dengan tingkah laku dan sikap hidup seseorang. Artinya bahwa tingkah laku dan sikap hidup dapat mengarah pada perbuatan yang efisien atau sebaliknya. Dengan adanya kesadaran, seseorang akan terdorong untuk membangkitkan semangat atau kehendak untuk melakukan sesuatu yang sesuai dengan apa yang disadarinya dalam hal ini yang dimaksudkan adalah efisiensi.

Pengertian efisiensi kerja menurut Sedarmayanti (2001 : 112) pada prinsipnya adalah perbandingan terbaik antara hasil yang diperoleh dengan kegitan yang dilakukan. Bekerja dengan efisien adalah bekerja dengan gerakan, usaha, waktu dan kelelahan yang sedikit mungkin. Dengan menggunakan cara kerja yang sederhana, penggunaan alat yang dapat membantu mempercepat penyelesaian tugas serta menghemat gerak dan tenaga, maka seseorang dapat dikatakan bekerja dengan efisien dan memperoleh hasil yang memuaskan. Tujuan utama pekerjaan kantor untuk mencapai efektivitas dan efisiensi kerja. Dalam pelaksanaan pekerjaan sering dijumpai kedalakendala yang dapat mempengaruhi kelancaran kerja. Diantaranya dapat berupa sistem, prosedur atau cara kerja yang kurang efisien dalam melaksanakan pekerjaan.

Menurut Mulyadi (2007 : 67) efisiensi seringkali dikaitkan dengan kinerja sutu organisasi karena efisiensi mencerminkan perbandingan antara keluaran (output) dengan masukan (input). Dalam berbagai literatur, efisiensi juga sering dikaitkan dengan produktivitas karena sama-sama menilai variabel input terhadap output. Pengertian produktivitas berkebalikan dengan pengertian efisiensi. Produktivitas dihitung dengan cara membagi output terhadap input, sedangkan efisiensi adalah input dibagi dengan output.

Berdasarkan pengertian di atas, dapat disimpulkan efisien kerja karyawan adalah hasil kerja (output). Baik kualitas maupun kuantitas yang dicapai sumber daya manusia persatuan periode waktu dalam melaksanakan tugas kerjanya sesuai dengan tanggung jawab yang diberikan kepadanya. Oleh sebab itu, perusahaan perlu melakukan 
manajemen efisiensi kerja karyawan dengan merumuskan tujuan dengan menjalin hubungan komunikasi yang baik dengan bawahan. Efisiensi karyawan yang tinggi akan tercapai apabila didukung oleh atribut individu, upaya kerja dan dukungan organisasi. Atribut individu, yang menentukan kapasitas untuk mengerjakan sesuatu.Atribut individu meliputi faktor individu (kemampuan atau keahlian, latar belakang pendidikan), dan faktor psikologis meliputi persepsi, attitude, personality, pembelajandan motivasi. Upaya kerja berkaitan dengan keinginan untuk mencapai keinginan sesuatu. Sedangkan dukungan organisasi, yang memberikan kesempatan untuk berbuat sesuatu. Dukungan organisasi, meliputi sumber daya, kepemimpinan, lingkungan kerja, struktur organisasi, dan desain pekerjaan.

\section{Tolak Ukur Efisiensi Karyawan}

Mutu kerja karyawan secara langsung menmpengaruhi Prestasi perusahaan. Guna mendapatkan kontribusi karyawan yang optimal, manajemen harus memahami strategi untuk mengelola, mengukur dan meningkatkan efisiensi, manajemen dimulai terlebih dahulu dengan menentukan tolak ukur Efisiensi.

Menurut Riani (2011:98) ada beberapa syarat tolak ukur efisiensi yang baik :

a. Tolak ukur yang baik haruslah mampu diukur dengan cara yang dapat dipercaya. Konsep keandalan pengukuran mempunyai dua komponen, yaitu stabilitas dan konsistensi. Stabilitas menyiratkan bahwa pengukuran yang dilakukan pada waktu yang berbeda haruslah mencapai hasil yang kira-kira serupa. Konsistensi menyiratkan bahwa pengukuran kriteria yang dilaksanakan dengan menggunakan metode yang berbeda atau orang yang berbeda haruslah mencapai hasil yang kira-kira sama.

b. Tolak ukur yang baik adalah harus sensitif terhadap masukan dan tindakan-tindakan dari pemegang jabatan.

Tolak ukur yang baik harus dapat diterima oleh individu yang mengetahui prestasinya sedang dinilai. Sangat penting untuk diperhatikan bahwa orang yang menghemat (efisien) sedang diukur merasa bahwa tolak ukur yang digunakan memberikan petunjuk yang akurat dan adil mengenai efisiensi kerja mereka.

\section{Faktor-Faktor Mempengaruhi Efisiensi} Kerja

Organisasi merupakan kumpulan orang yang memiliki kompetensi yang berbeda-beda yang saling tergantung satu dengan yang lainnya, yang berusaha untuk mewujudkan kepentingan bersama mereka, dengan memanfaatkan berbagai sumber daya. Pada dasarnya tujuan bersama yang ingin diwujudkan oleh organisasi adalah mencari keuntungan. Oleh karena itu diperlukan karyawan yang mempunyai menghemat waktu yang tinggi. Efisiensi menunjukkan catatan tentang hasil-hasil yang diperoleh dari fungsi-fungsi pekerjaan tertentu atau kegiatan tertentu selamakurun waktu tertentu.

Menurut Simanjuntak (2005:10),'Efisiensi kerja karyawan dipengaruhi oleh banyak faktor yang dapat digolongkan pada tiga kelompok, kompetensi individu, yang bersangkutan, dukungan organisasi dean dukungan manajemen".

\section{a. Kompetensi Individu}

Kompetensi individu adalah kemampuan dan keterampilan melakukan kerja. Kompetensi setiap orang dipengaruhi oleh beberapa faktor, yaitu kemampuan, pendidikan dan pelatihan, pengalaman kerja, motivasi dan etos kerja. Kemampuan kerja setiap orang dipengaruhi oleh kebugaran fisik dan kesehatan karyawan yang bersangkutan, pendidikan, pelatihan dan pengalaman kerjanya. Kebugaran fisik membuat orang mampu dan tahan bekerja keras dan lama. Sebaliknya, pekerja yang kekurangan gizi akan cepat lemah dan lelah, serta tidak mampu melakukan pekerjaan yang berat. Demikian juga gangguan kejiwaan akibat rasa frustasi dan masalah social ekonomi, hal ini membuat tenaga kerja tidak konsisten serta tidak terkonsentrasi melakukan pekerjaan.

\section{b. Dukungan Organisasi}

Tingginya efisiensi karyawan juga tergantung pada dukungan organisasi dalam bentuk pengorganisasian, penyediaan sarana dan prasarana kerja, kondisi kerja serta syarat kerja. Pengorganisasian dimaksudkan untuk memberikan kejelasan bagi setiap unit kerja dan setiap orang perlu memiliki dan memahami uraian jabatan dan uraian tugas yang jelas. Penyediaan sarana dan alat kerja langsung mempengaruhi penghematan waktu seseorang. Penggunaan peralatan dan teknologi maju bukan saja dimaksudkan untuk meningkatkan efisiensi, akan tetapi juga dipandaang untuk memberikan kemudahan dan kenyamanan kerja.

Kondisi kerja mencakup kenyamanan lingkungn kerja, aspek keselamatan dan kesehatan kerja, sistem pengupahan, jaminan sosial, serta keamanan dan keharmonisan hubungan industrial. Hal-hal tersebut mempengaruhi kenyamanan untuk melaksanakan tugas yang lebih lanjut mempengaruhi efisiensi setiap orang. Program keselamatan dan kesehatan kerja perlu ditingkatkan bukan saja untuk menghindari kecelakaan kerja, kerusakan alat dan gangguan produksi, akan tetapi juga untuk meningkatkan prestasi kerja atau penghematan waktu kerja.

Syarat-syarat kerja yang memuat hak dan kewajiban pekerja serta kewenangan dan melaksanakan kewajiban pengusaha akan memberikan kepastian bagi pekerja untuk melaksanakan tugasnya dengan baik dan dengan penuh tanggung jawab. Pemberian kompensasi yang adil dan layak melalui system pengupahan akan mendorong setiap pekerja meningkatkan penghematan waktu. Dalam hubungan industrial yang aman dan harmonis, efisiensi pekerja tidak perlu terganggu oleh demontrasi dan pemogokan. 


\section{c. Dukungan Manajemen}

Efisien dan penghematan waktu setiap orang dipengaruhi oleh kemampuan manajerial para manajemen atau pimpinan, baik dengan membangun system kerja dan hubungan industrial yang aman dan harmonis, maupun dengan mengembangkan kompetensi pekerja yang terlibat dalam aktifitas perusahaan, demikian juga dengan menumbuhkan motivasi dan memobilisasi seluruh pegawai untuk bekerja secara optimal dalam rangka pengembangan kompetensi pekerja, manajemen dapat melakukan antara lain:

1) Mengidentifikasi dan mengoptimalkan pemanfaatan kekuatan, keunggulan,dan potensi yang dimiliki oleh setiap pekerja.

2) Mendukung pekerja untuk terus belajar meningkatkan wawasan dan pengetahuannya.

3) Membuka kesempatan yang seluas-luasnya kepada pekerja untuk belajar, baik secara pribadi maupun melalui pendidikan dan pelatihan yang dirancang dan diprogramkan.

4) Membantu setiap orang menghadapi kesulitan dalam melakukan tugas.

Menurut Gani (2009:20), faktor yang mempengaruhi efisiensi (menghemat waktu) adalah:

1) Profesionalisme diukur dari pendidikan, pelatihan teknis, masa kerja (pengalaman), dan tersedianya peralatan kerja untuk mempercepat pelayanan.

2) Disipin diukur dari waktu jam kerja, ketaatan terhadap aturan, jadwal pekerjaan dan melaksanakan pekerjaan.

3) Motivasi kerja diukur dari kesejahteraan, penghargaan, lingkungan kerja, dan ruangan kerja.

\section{PEMBAHASAN}

\section{Analisa}

Berdasarkan data-data yang diperoleh dari hasil kuesioner yang telah ditabulasikan dilakukan pengujian korelasi analisis faktor-faktor efisiensi kerja karyawan. Analisis faktor terdiri dari :

\section{a. KMO dan Barlett's Test}

Dari hasil kuesioner setelah ditabulasi, dilakukan uji KMO dan Barlett's Test dengan menggunakan SPSS. Dari hasil output SPSS untuk 14 pernyataan yang dijawab oleh 70 responden dalam kuesioner, diperoleh hasil sebagai berikut :

\section{Tabel 1.}

\section{KMO and Bartlett's Test}

\begin{tabular}{|ll|l|}
\hline Kaiser-Meyer-Olkin Measure of & .742 \\
Sampling Adequacy. & \\
Bartlett's Test of & Approx. Chi-Square & \\
Sphericity & & 219.698 \\
& Df & 91 \\
& Sig. & .000 \\
\hline
\end{tabular}

Dari hasil output SPSS pada tabel KMO and Barlett's Test terlihat angka Kaiser-Meyer-Olkin Meausre of Sampling Adequacy sebesar 0,742 di atas 0,5 ; dengan signfikansi 0,000 adalah di bawah 0,5 , maka variabel dan sampel sudah layak untuk dianalisis lebih lanjut. Dilihat dari angka Chi-square sebesar 219,698 artinya keempat belas faktor yang mempengaruhi efisiensi kerja karyawan pada PT. Petro Fajar Berlian, Medan dapat diterima pada tingkat signifikansi $5 \%$.

\section{b. Anti Image Mactries}

Nilai Anti Image Matries adalah nilai dengan simbol (a) yang menunjukkan besaran Measure of Sampling Adequarcy (MSA) masingmasing faktor. Besaran MSA tersebut menunjukkan kecukupan pengaruh dari faktor tersebut terhadap faktor-faktor yang mempengaruhi efisiensi kerja karyawan. Besar nilai MSA yang diperoleh disajikan pada Tabel 2.

Tabel 2.

Nilai Measure of Sampling Adequarcy (MSA)

\begin{tabular}{|l|c|}
\hline \multicolumn{1}{|c|}{$\begin{array}{c}\text { Faktor-Faktor yang } \\
\text { mempengaruhi } \\
\text { efisiensi kerja karyawan }\end{array}$} & $\begin{array}{c}\text { Measure of } \\
\text { Sampling } \\
\text { Adequarcy }\end{array}$ \\
\hline Kemampuan fisik $\left(\mathrm{V}_{1}\right)$ & 0,798 \\
\hline Pendidikan dan pelatihan $\left(\mathrm{V}_{2}\right)$ & 0,736 \\
\hline Pengalaman kerja $\left(\mathrm{V}_{3}\right)$ & 0,723 \\
\hline Kesejahteraan $\left(\mathrm{V}_{4}\right)$ & 0,842 \\
\hline Syarat kerja $\left(\mathrm{V}_{5}\right)$ & 0,675 \\
\hline Lingkungan Kerja $\left(\mathrm{V}_{6}\right)$ & 0,750 \\
\hline Waktu Jam Kerja $\left(\mathrm{V}_{7}\right)$ & 0,668 \\
\hline Ketaatan $\left(\mathrm{V}_{8}\right)$ & 0,763 \\
\hline Jadwal pekerjaan $\left(\mathrm{V}_{9}\right)$ & 0,768 \\
\hline Pengorganisasian $\left(\mathrm{V}_{10}\right)$ & 0,792 \\
\hline Sarana dan prasarana kerja $\left(\mathrm{V}_{11}\right)$ & 0,703 \\
\hline Kondisi ruangan kerja $\left(\mathrm{V}_{12}\right)$ & 0,848 \\
\hline Penghargaan $\left(\mathrm{V}_{13}\right)$ & 0,694 \\
\hline Kepemimpinan $\left(\mathrm{V}_{14}\right)$ & 0,708 \\
\hline
\end{tabular}

Dilihat dari nilai MSA, berarti keempat belas faktor yang mempengaruhi efisiensi kerja karyawan dapat diproses lebih lanjut karena nilai MSAnya rata-rata di atas 0,30 . Angka Anti Image Covariance, menunjukkan nilai korelasi positif antara satu variabel dengan variabel lainnya. Hal ini menunjukkan bahwa setiap indikator berpengaruh positif terhadap indikator lainnya.

\section{c. Communalities}

Communalities pada dasarnya adalah jumlah varians (biasa dalam persentae) dari suatu variabel mula-mula yang bisa dijelaskan oleh faktor yang ada. Semua variabel dijelaskan oleh faktor yang terbentuk dengan ketentuan semakin besar communalities maka semakin erat hubungan variabel yang bersangkutan dengan faktor yang terbentuk. Hasil communilities yang diperoleh dari output SPSS disajikan pada Tabel 3. 
Tabel 3.

Communalities

\begin{tabular}{|l|l|l|}
\hline $\begin{array}{l}\text { Faktor-Faktor yang } \\
\text { Mempengaruhi Efisiensi } \\
\text { kerja karyawan }\end{array}$ & Initial & Extraction \\
\hline Kemampuan fisik $\left(\mathrm{V}_{1}\right)$ & 1.000 & .390 \\
Pendidikan dan pelatihan & 1.000 & .618 \\
$\left(\mathrm{~V}_{2}\right)$ & 1.000 & .569 \\
Pengalaman kerja $\left(\mathrm{V}_{3}\right)$ & 1.000 & .579 \\
Kesejahteraan $\left(\mathrm{V}_{4}\right)$ & 1.000 & .684 \\
Syarat kerja $\left(\mathrm{V}_{5}\right)$ & 1.000 & .710 \\
Lingkungan Kerja $\left(\mathrm{V}_{6}\right)$ & 1.000 & .632 \\
Waktu Jam Kerja $\left(\mathrm{V}_{7}\right)$ & 1.000 & .706 \\
Ketaatan $\left(\mathrm{V}_{8}\right)$ & 1.000 & .590 \\
Jadwal pekerjaan $\left(\mathrm{V}_{9}\right)$ & 1.000 & .719 \\
Pengorganisasian $\left(\mathrm{V}_{10}\right)$ & & \\
Sarana dan prasarana kerja & 1.000 & .734 \\
$\left(\mathrm{~V}_{11}\right)$ & & \\
Kondisi ruangan kerja & 1.000 & .450 \\
$\left(\mathrm{~V}_{12}\right)$ & 1.000 & .762 \\
Penghargaan $\left(\mathrm{V}_{13}\right)$ & 1.000 & .695 \\
Kepemimpinan $\left(\mathrm{V}_{14}\right)$. &
\end{tabular}

Berdasarkan nilai communalities setiap variabel dapat diberikan penjelasan sebagai berikut :

1) Untuk variabel kemampuan fisik, angka 0,390 artinya 39,0 \% dari variabel kemampuan fisik dapat dijelaskan oleh faktor yang nanti terbentuk (component Matrix).

2) Untuk variabel pendidikan dan pelatihan, angka 0,618 artinya $61,8 \%$ dari variabel pendidikan dan pelatihan dapat dijelaskan oleh faktor yang nanti terbentuk (component Matrix).

3) Untuk variabel pengalaman kerja, angka 0,569 artinya $56,9 \%$ dari variabel pengalaman kerja dapat dijelaskan oleh faktor yang nanti terbentuk (component Matrix).

4) Untuk variabel kesejahteraan, angka 0,579 artinya 57,9 \% dari variabel kesejahteraan dapat dijelaskan oleh faktor yang nanti terbentuk (component Matrix).

5) Untuk variabel syarat kerja, angka 0,684 artinya $68,4 \%$ dari variabel syarat kerja dapat dijelaskan oleh faktor yang nanti terbentuk (component Matrix).

6) Untuk variabel lingkungan kerja, angka 0,710 artinya $71,0 \%$ dari variabel lingkungan kerja dapat dijelaskan oleh faktor yang nanti terbentuk (component Matrix).

7) Untuk variabel waktu jam kerja, diperoleh angka 0,632 artinya $63,2 \%$ dari variabel waktu jam kerja dapat dijelaskan oleh faktor yang nanti terbentuk (component Matrix).

8) Untuk variabel ketaatan, angka 0,706 artinya $70,6 \%$ dari variabel ketaatan dapat dijelaskan oleh faktor yang nanti terbentuk (component Matrix).
9) Untuk variabel jadwal pekerjaan, angka 0,590 artinya $59,9 \%$ dari variabel jadwal pekerjaan dapat dijelaskan oleh faktor yang nanti terbentuk (component Matrix).

10) Untuk variabel pengorganisasian, angka 0,719 artinya $71,9 \%$ dari variabel pengorganisasian dapat dijelaskan oleh faktor yang nanti terbentuk (component Matrix).

11)Untuk variabel sarana dan prasarana kerja, angka 0,734 artinya 73,4 \% dari variabel sarana dan prasarana dapat dijelaskan oleh faktor yang nanti terbentuk (component Matrix).

12) Untuk variabel kondisi ruangan kerja, angka 0,450 artinya 45,0 \% dari variabel kondisi ruangan kerja dijelaskan oleh faktor yang nanti terbentuk (component Matrix).

13) Untuk variabel penghargaan, angka 0,762 artinya $76,2 \%$ dari variabel penghargaan dapat dijelaskan oleh faktor yang nanti terbentuk (component Matrix).

14) Untuk variabel kepemimpinan, angka 0,695 artinya 69,5\% dari variabel kepemimpinan dapat dijelaskan oleh faktor yang nanti terbentuk (component Matrix).

\section{d. Total Variance Explained}

Tabel total variance explained menunjukkan korelasi antara masing-masing variabel dengan faktor 1 , faktor 2 , faktor 3 , faktor 4 , faktor 5 , faktor 6 , faktor 7 , faktor 8 , faktor 9 , faktor 10 , faktor 11, faktor 12, faktor 13 dan faktor 14. Penentuan variabel yang masuk masing-masing faktor dilakukan dengan membandingkan besaran korelasi pada setiap baris. Hasil pengujian Total Variance Explained dapat dilihat pada Tabel 4.

Tabel 4.

\section{Total Variance Explained}

\begin{tabular}{|c|c|c|c|c|c|c|c|c|c|}
\hline \multirow{2}{*}{$\begin{array}{c}\text { Com } \\
\text { pone } \\
\text { nt }\end{array}$} & \multicolumn{3}{|c|}{$\begin{array}{c}\text { Initial } \\
\text { Eigenvalues }\end{array}$} & \multicolumn{3}{|c|}{$\begin{array}{l}\text { Extraction Sums of } \\
\text { Squared Loadings }\end{array}$} & \multicolumn{3}{|c|}{$\begin{array}{l}\text { Rotation Sums of } \\
\text { Squared Loadings }\end{array}$} \\
\hline & Total & $\begin{array}{c}\% \text { of } \\
\text { Varian } \\
\mathrm{e}\end{array}$ & $\begin{array}{c}\text { Cumulativ } \\
\text { e }\end{array}$ & Total & $\begin{array}{c}\% \text { of } \\
\text { Varian } \\
\mathrm{e}\end{array}$ & $\begin{array}{l}\text { Cumul } \\
\text { tive } \%\end{array}$ & Total & \begin{tabular}{|c}
$\begin{array}{c}\% \text { of } \\
\text { Varian } \\
\text { e }\end{array}$ \\
\end{tabular} & $\begin{array}{c}\text { cCumul } \\
\text { tive } \%\end{array}$ \\
\hline 1 & 4.042 & 28.871 & 28.871 & 4.042 & 28.871 & 28.871 & 1.855 & 13.247 & 13.247 \\
\hline 2 & 1.444 & 10.315 & 39.186 & 1.444 & 10.315 & 39.186 & 1.840 & 13.145 & 26.392 \\
\hline 3 & 1.227 & 8.764 & 47.950 & 1.227 & 8.764 & 47.950 & 1.809 & 12.924 & 39.316 \\
\hline 4 & 1.092 & 7.803 & 55.753 & 1.092 & 7.803 & 55.753 & 1.682 & 12.015 & 51.331 \\
\hline 5 & 1.035 & \begin{tabular}{|l|}
7.393 \\
\end{tabular} & 63.146 & 1.035 & 7.393 & 63.146 & 1.654 & 11.815 & 63.146 \\
\hline 6 & .924 & 6.600 & 69.746 & & & & & & \\
\hline 7 & .798 & 5.698 & 75.444 & & & & & & \\
\hline 8 & .710 & 5.069 & 80.513 & & & & & & \\
\hline & .575 & 4.106 & 84.620 & & & & & & \\
\hline 10 & .564 & 4.028 & $88.647 \mid$ & & & & & & \\
\hline 11 & .496 & 3.544 & 92.192 & & & & & & \\
\hline 12 & .435 & 3.109 & 95.301 & & & & & & \\
\hline 13 & 376 & 2.685 & 97.986 & & & & & & \\
\hline 14 & 282 & 2.014 & 100.000 & & & & & & \\
\hline
\end{tabular}


Tabel 4 menunjukkan bahwa faktor-faktor yang diambil adalah yang memiliki nilai total initial eigenalues di atas 1 , sehingga diperoleh 5 faktor yang paling berpengaruh. Total kelima faktor tersebut sebesar 63,146 \%, yang berarti bahwa kelima faktor tersebut dapat menjelaskan 63,164\% dari variabilitas keempat belas variabel yang mempengaruhi efisiensi kerja karyawan. Eingenvalues menunjukkan kepentingan relatif masing-masing faktor dalam menghitung varians keempat belas variabel yang dianalisis. Jumlah angka eingenvalues untuk keempat belas variabel adalah : $(2,781+2,196+1,792+1,425+1,216+$ $1,203+1,126+1,030+1,004+0,937+0,905+$ $0,791+0,769+0,589+0,576+0,531+0,465+$ $0,383+0,204+0,078)=20$.

\section{e. Component Matrix}

Faktor loading yaitu besarnya korelasi antara masing-masing variabel dengan faktor 1 , faktor 2, faktor 3, faktor 4 dan faktor 5. Penentuan variabel dari msing-masing faktor dilakukan dengan memperbandingkan besaran korelasi setiap baris. Angka yang paling besar menunjukkan korelasi paling kuat. Angka korelasi di bawah 0,50 mengindikasikan korelasi yang lemah dan jika korelasinya di atas 0,50 mengindikasikan korelasinya kuat. Component matrix disajikan pada Tabel 5.

Tabel 5.

Compenent Matrix

\begin{tabular}{|c|c|c|c|c|c|}
\hline \multirow{2}{*}{$\begin{array}{c}\text { Faktor-Faktor yang } \\
\text { Mempengaruhi } \\
\text { Efisiensi Kerja } \\
\text { Karyawan } \\
\end{array}$} & \multicolumn{5}{|c|}{ Component } \\
\hline & 1 & 2 & 3 & 4 & 5 \\
\hline Ketaatan $\left(\mathrm{V}_{8}\right)$ & .603 & .079 & .080 & -.489 & -.302 \\
\hline Syarat kerja $\left(V_{5}\right)$ & .593 & -.138 & -.494 & .158 & .211 \\
\hline $\begin{array}{l}\text { Kemampuan fisik } \\
\left(\mathrm{V}_{1}\right)\end{array}$ & .574 & -.052 & -.108 & -.207 & -.055 \\
\hline $\begin{array}{l}\text { Pengorganisasian } \\
\left(\mathrm{V}_{10}\right)\end{array}$ & .553 & .051 & .303 & -.430 & .367 \\
\hline $\begin{array}{l}\text { Pengalaman kerja } \\
\left(\mathrm{V}_{3}\right)\end{array}$ & .546 & -.446 & .196 & .107 & .153 \\
\hline $\begin{array}{l}\text { Jadwal pekerjaan } \\
\left(\mathrm{V}_{9}\right)\end{array}$ & .539 & -.159 & .477 & -.089 & .197 \\
\hline $\begin{array}{l}\text { Kondisi ruangan } \\
\text { kerja }\left(\mathrm{V}_{12}\right)\end{array}$ & .521 & .156 & -.044 & .313 & -.234 \\
\hline $\begin{array}{l}\text { Kepemimpinan } \\
\left(\mathrm{V}_{14}\right)\end{array}$ & .518 & -.429 & .079 & .407 & .267 \\
\hline $\begin{array}{l}\text { Waktu Jam Kerja } \\
\left(\mathrm{V}_{7}\right)\end{array}$ & .511 & .366 & -.396 & -.238 & .151 \\
\hline Penghargaan $\left(\mathrm{V}_{13}\right)$ & .504 & .288 & .349 & .447 & -.322 \\
\hline $\begin{array}{l}\text { Lingkungan Kerja } \\
\left(\mathrm{V}_{6}\right)\end{array}$ & .501 & .448 & -.370 & .211 & .277 \\
\hline $\begin{array}{l}\text { Sarana dan } \\
\text { prasarana kerja } \\
\left(\mathrm{V}_{11}\right)\end{array}$ & .538 & -.540 & -.286 & -.099 & -.249 \\
\hline $\begin{array}{l}\text { Pendidikan dan } \\
\text { pelatihan }\left(\mathrm{V}_{2}\right)\end{array}$ & .483 & .521 & .314 & .078 & .094 \\
\hline Kesejahteraan $\left(\mathrm{V}_{4}\right)$ & .524 & -.021 & -.055 & -.038 & -.547 \\
\hline
\end{tabular}

Berdasarkan tabel tersebut di atas, maka penjelasan component matrix adalah sebagai berikut :

1) Variabel ketaatan $\left(V_{8}\right)$, korelasi antara variabel ketaatan dengan faktor 1 adalah yang tertinggi yaitu 0,603 (kuat). Dengan demikian variabel ini dapat dimasukkan sebagai faktor 1 .
2) Variabel syarat kerja $\left(\mathrm{V}_{5}\right)$, korelasi antara variabel syarat kerja dengan faktor 1 adalah yang tertinggi yaitu 0,593 (kuat). Dengan demikian variabel ini dimasukkan sebagai faktor 1

3) Variabel kemampuan fisik yang tersedia $\left(V_{1}\right)$, korelasi antara variabel kemampuan fisik yang tersedia dengan faktor 1 adalah yang tertinggi yaitu 0,574 (kuat). Dengan demikian variabel ini dimasukkan sebagai faktor 1 .

4) Variabel pengorganisasian $\left(V_{10}\right)$, korelasi antara variabel pengorganisasian dengan faktor 1 adalah yang tertinggi yaitu 0,553 (kuat). Dengan demikian variabel ini dimasukkan sebagai faktor 1 .

5) Variabel pengalaman kerja $\left(\mathrm{V}_{3}\right)$, korelasi antara variabel pengalaman kerja dengan faktor 1 adalah yang tertinggi yaitu 0,546 (kuat). Dengan demikian variabel ini dimasukkan sebagai faktor 1 .

6) Variabel jadwal pekerjaan $\left(\mathrm{V}_{9}\right)$, korelasi antara variabel jadwal pekerjaan dengan faktor 1 adalah yang tertinggi yaitu 0,539 (kuat). Dengan demikian variabel ini dimasukkan sebagai faktor 1 .

7) Variabel kondisi ruangan kerja $\left(\mathrm{V}_{12}\right)$, korelasi antara variabel kondisi ruangan kerja dengan faktor 1 adalah yang tertinggi yaitu 0,521 (kuat). Dengan demikian variabel ini dimasukkan sebagai faktor 1 .

8) Variabel kepemimpinan $\left(\mathrm{V}_{14}\right)$, korelasi antara variabel kepemimpinan dengan faktor 1 adalah yang tertinggi yaitu 0,518 (kuat). Dengan demikian variabel ini dimasukkan sebagai faktor 1 .

9) Variabel waktu jam kerja $\left(\mathrm{V}_{7}\right)$, korelasi antara variabel waktu jam kerja dengan faktor 1 adalah yang tertinggi yaitu 0,511 (kuat). Dengan demikian variabel ini dimasukkan sebagai faktor 1.

10) Variabel penghargaan $\left(V_{13}\right)$, korelasi antara variabel penghargaan dengan faktor 1 adalah yang tertinggi yaitu 0,504 (kuat). Dengan demikian variabel ini dimasukkan sebagai faktor 1.

11) Variabel lingkungan kerja $\left(V_{6}\right)$, korelasi antara variabel lingkungan kerja dengan faktor 1 adalah yang tertinggi yaitu 0,501 (kuat). Dengan demikian variabel ini dimasukkan sebagai faktor 1.

12) Variabel sarana dan prasarana kerja $\left(V_{11}\right)$, korelasi antara variabel sarana dan prasarana kerja dengan faktor 1 adalah yang tertinggi yaitu 0,538 (kuat). Dengan demikian variabel ini dimasukkan sebagai faktor 1 .

13) Variabel pendidikan dan pelatihan $\left(V_{2}\right)$, korelasi antara variabel pendidikan dan pelatihan dengan faktor 2 adalah yang tertinggi yaitu 0,521 (tinggi). Dengan demikian variabel ini dimasukkan sebagai faktor 2 .

14) Variabel kesejahteraan $\left(V_{4}\right)$, korelasi antara variabel kesejahteraan dengan faktor 1 adalah yang teringgi yaitu 0,524 (kuat). Dengan 
demikian variabel ini dimasukkan sebagai faktor 1.

\section{f. Rotated Component Matrix}

Rotated component matrix berguna untuk memperjelas variabel-variabel mana yang masuk dalam tiap-tiap faktor. Suatu variabel dapat dimasukkan ke dalam suatu faktor jika nilai korelasinya di atas 0,50 . Jika korelasinya di bawah 0,50 , berarti hubungan variabel tersebut dengan faktor tertentu lemah. Banyak sekali faktor loading yang berubah setelah dilakukan proses rotasi, ada yang faktor loadingnya menjadi lebih kecil atau lebih besar. Hasil analisis rotated component matrix disajikan pada Tabel 6.

Tabel 6.

Rotated Component Matrix

\begin{tabular}{|c|c|c|c|c|c|}
\hline Faktor-Faktor & \multicolumn{5}{|c|}{ Component } \\
\hline $\begin{array}{l}\text { Mempengaruhi } \\
\text { Efisiensi Kerja } \\
\text { Karyawan }\end{array}$ & 1 & 2 & 3 & 4 & 5 \\
\hline $\begin{array}{l}\text { Kepemimpinan } \\
\left(\mathrm{V}_{14}\right)\end{array}$ & .804 & .003 & .108 & .094 & .167 \\
\hline $\begin{array}{l}\text { Pengalaman } \\
\text { kerja }\left(V_{3}\right)\end{array}$ & 663 & .194 & -.018 & .290 & .087 \\
\hline $\begin{array}{lr}\text { Sarana } & \text { dan } \\
\text { prasarana } & \text { kerja } \\
\left(\mathrm{V}_{11}\right) & \end{array}$ & 488 & .685 & 100 & -.051 & -.119 \\
\hline Ketaatan $\left(\mathrm{V}_{8}\right)$ & -.096 & .668 & .120 & 465 & .140 \\
\hline $\begin{array}{l}\text { Kesejahteraan } \\
\left(\mathrm{V}_{4}\right)\end{array}$ & .060 & .667 & .050 & -.007 & .358 \\
\hline $\begin{array}{l}\text { Kemampuan } \\
\text { fisik }\left(\mathrm{V}_{1}\right)\end{array}$ & 180 & .449 & .281 & .269 & .064 \\
\hline $\begin{array}{l}\text { Lingkungan } \\
\text { Kerja }\left(\mathrm{V}_{6}\right)\end{array}$ & .073 & -.049 & .785 & .057 & .289 \\
\hline $\begin{array}{l}\text { Waktu Jam } \\
\text { Kerja }\left(\mathrm{V}_{7}\right)\end{array}$ & -.106 & .253 & .709 & .231 & .033 \\
\hline Syarat kerja $\left(V_{5}\right)$ & .479 & .243 & 626 & -.052 & -.009 \\
\hline $\begin{array}{l}\text { Pengorganisasia } \\
\mathrm{n}\left(\mathrm{V}_{10}\right)\end{array}$ & 146 & .121 & 196 & .803 & -.019 \\
\hline $\begin{array}{l}\text { Jadwal } \\
\text { pekerjaan }\left(\mathrm{V}_{9}\right)\end{array}$ & 396 & .101 & -.075 & .614 & .201 \\
\hline $\begin{array}{l}\text { Penghargaan } \\
\left(\mathrm{V}_{13}\right)\end{array}$ & 137 & 130 & .006 & .084 & .848 \\
\hline $\begin{array}{l}\text { Pendidikan dan } \\
\text { pelatihan }\left(V_{2}\right)\end{array}$ & -.074 & -.061 & 271 & 455 & .573 \\
\hline $\begin{array}{l}\text { Kondisi ruangan } \\
\text { kerja }\left(V_{12}\right)\end{array}$ & .189 & .262 & .251 & -.045 & .530 \\
\hline
\end{tabular}

Berdasarkan tabel tersebut di atas, maka penjelasan Rotated component matrix adalah sebagai berikut :

1) Variabel kepemimpinan $\left(\mathrm{V}_{14}\right)$, korelasi antara variabel kepemimpinan dengan faktor 1 adalah yang tertinggi yaitu 0,804 (kuat). Dengan demikian variabel ini dapat dimasukkan sebagai faktor 1 .

2) Variabel pengalaman kerja $\left(\mathrm{V}_{3}\right)$, korelasi antara variabel pengalaman kerja dengan faktor 1 adalah yang tertinggi yaitu 0,663 (kuat). Dengan demikian variabel ini dimasukkan sebagai faktor 1.
3) Variabel sarana dan prasarana kerja $\left(\mathrm{V}_{11}\right)$, korelasi antara variabel sarana dan prasarana kerja dengan faktor 2 adalah yang tertinggi yaitu 0,685 (kuat). Dengan demikian variabel ini dimasukkan sebagai faktor 2 .

4) Variabel ketaatan $\left(\mathrm{V}_{8}\right)$ korelasi antara variabel ketaatan dengan faktor 2 adalah yang tertinggi yaitu 0,668 (kuat). Dengan demikian variabel ini dimasukkan sebagai faktor 2 .

5) Variabel kesejahteraan $\left(\mathrm{V}_{4}\right)$, korelasi antara variabel kesejahteraan dengan faktor 2 adalah yang tertinggi yaitu 0,667 (kuat). Dengan demikian variabel ini dimasukkan sebagai faktor 2.

6) Variabel kemampuan fisik $\left(\mathrm{V}_{1}\right)$, korelasi antara variabel kemampuan fisik dengan faktor 2 adalah yang tertinggi yaitu 0,449 (lemah). Dengan demikian variabel ini dimasukkan sebagai faktor 2 .

7) Variabel lingkungan kerja $\left(V_{6}\right)$, korelasi antara variabel lingkungan kerja dengan faktor 3 adalah yang tertinggi yaitu 0,785 (kuat). Dengan demikian variabel ini dimasukkan sebagai faktor 3.

8) Variabel waktu jam kerja $\left(\mathrm{V}_{7}\right)$, korelasi antara variabel waktu jam kerja dengan faktor 3 adalah yang tertinggi yaitu 0,709 (kuat). Dengan demikian variabel ini dimasukkan sebagai faktor 3 .

9) Variabel syarat kerja $\left(\mathrm{V}_{5}\right)$, korelasi antara variabel syarat kerja dengan faktor 3 adalah yang tertinggi yaitu 0,626 (kuat). Dengan demikian variabel ini dimasukkan sebagai faktor 3 .

10) Variabel pengorganisasian $\left(V_{10}\right)$, korelasi antara variabel pengorganisasian dengan faktor 4 adalah yang tertinggi yaitu 0,803 (kuat). Dengan demikian variabel ini dimasukkan sebagai faktor 4.

11) Variabel jadwal pekerjaan $\left(V_{9}\right)$, korelasi antara variabel jadwal pekerjaan dengan faktor 4 adalah yang tertinggi yaitu 0,614 (kuat). Dengan demikian variabel ini dimasukkan sebagai faktor 4.

12) Variabel penghargaan $\left(\mathrm{V}_{13}\right)$, korelasi antara variabel penghargaan dengan faktor 5 adalah yang tertinggi yaitu 0,848 (kuat). Dengan demikian variabel ini dimasukkan sebagai faktor 5.

13) Variabel pendidikan dan pelatihan $\left(\mathrm{V}_{2}\right)$, korelasi antara variabel pendidikan dan pelatihan dengan 
faktor 5 adalah yang tertinggi yaitu 0,573 (kuat). Dengan demikian variabel ini dimasukkan sebagai faktor 5 .

14) Variabel kondisi ruangan kerja $\left(V_{12}\right)$, korelasi antara variabel kondisi ruangan kerja dengan faktor 5 adalah yang tertinggi yaitu 0,530 (kuat). Dengan demikian variabel ini dimasukkan sebagai faktor 5 .

\section{g. Component Transformation Matrix}

Selanjutnya hasil analisis component transformation matrix disajikan pada Tabel 7.

Tabel 7.

Component Transformation Matrix

\begin{tabular}{|c|l|c|c|c|c|}
\hline Component & \multicolumn{1}{|c|}{1} & \multicolumn{1}{|c|}{2} & 3 & \multicolumn{1}{c|}{4} & \multicolumn{1}{|c|}{5} \\
\hline 1 & .448 & .502 & .450 & .431 & .399 \\
2 & -.706 & -.255 & .437 & .135 & .477 \\
3 & .042 & -.238 & -.674 & .579 & .388 \\
4 & .448 & -.411 & .030 & -.549 & .572 \\
5 & .312 & -.676 & .389 & .399 & -.368 \\
\hline
\end{tabular}

Berdasarkan Tabel 7, dapat dijelaskan bahwa pada faktor 1 bernilai 0,502; faktor 2 bernilai 0,477 , faktor 3 bernilai 0,579 , faktor 4 bernilai 0,572 dan faktor 5 bernilai 0,399 . Kelima faktor yang terbentuk sudah tepat karena mempunyai nilai korelasi yang cukup tinggi. Dengan demikian, antara faktor cenderung terjadi interkorelasi.

\section{Evaluasi}

Faktor yang paling dominan mempengaruhi efisiensi kerja karyawan pada PT. Petro Fajar Berlian, Medan dengan nilai korelasi lebih besar dari 0,80 yaitu kondisi ruangan kerja $(0,848)$. Hal ini menunjukkan bahwa kondisi ruangan kerja sangat mempengaruhi efisiensi kerja karyawan pegawai. Hal ini disebabkan dengan kondisi ruangan kerja yang nyaman dan memadai, karyawan akan lebih giat bekerja, karena dengan tersedianya fasilitas ruangan akan mendukung proses pekerjaan, sehingga pekerjaan yang dilakukan menjadi lebih cepat dan hasilnya menjadi lebih baik.

Kondisi ruangan kerja yang menyenangkan dan tidak membosankan dapat menambah gairah kerja. Dalam rangka mendukung efisiensi kerja maka secara tidak langsung susana ruangan kerja sangat mendukung efisiensi kerja karyawan yang bekerja di kantor tersebut. Oleh karena itu, setiap organisasi perlu menciptakan kondisi ruangan kerja yang mendukung kelancaran karyawan dalam melaksanakan pekerjaannya terutama perusahaan manufaktur dimana banyak proses produksinya yang bisa memberi dampak negatif terhadap staf kantor dan salah satunya dengan melakukan penataan ruangan kerja yang baik.
Kondisi ruangan kerja dapat berupa lingkungan fisik maupun non fisik. Lingkungan perusahaan meliputi keadaan penerangan, keadaan sirkulasi udara dan tata ruang. Sedangkan lingkungan non fisik meliputi suasana kerja, keamanan dan lain-lain. Dengan lingkungan kerja yang baik dapat membuat karyawan merasa nyaman dan betah dalam bekerja, sehingga mendorong karyawan bersemangat dalam melakukan pekerjaan sehari-hari terutama di perusahaan manufacture yang dimana ada proses produksi yang membutuhkan alatalat atau mesin-mesin berat yang secara tidak langsung menganggu staf kantor. Begitu juga sebaliknya lingkungan kerja yang tidak layak dan tidak sesuai dapat mengganggu karyawan dalam bekerja seperti dekat dengan kebisingan mesin dan resiko produksi lainnya yang dekat dekat tata ruang kantor juga termasuk dalam lingkungan kerja. Tata ruang yang baik mendukung suatu metode untuk membenahi dan menyusun alat-alat perkantoran dan perlengkapan di dalam ruangan yang bertujuan untuk memberikan sarana bagi karyawan. Tata ruang kantor merupakan suatu segi yang paling dekat dengan pelaksanaan kerja karyawan sehari-hari. Adanya lingkungan kerja yang nyaman khususnya tata ruang kantor yang baik akan memberikan dorongan kepada karyawan untuk bekerja sungguhsungguh sehingga dapat meningkatkan efisiensi kerja.

Ruang kerja yang jauh dari kebisingan sangat penting agar konsentrasi karyawan terjaga dan jauh dari resiko produksi pun sangat penting karena di dalam kantor terdapat arsip-arsip kantor yang sangat penting tentang kegiatan perusahaan maka dari itu jauh dari ruang produksi untuk meminimalkan resiko sangat penting. Terlebih dari tata letak kantor yang harus nyaman karena perusahaan manufacture terdapat banyak mesin akan memungkinkan untuk timbul udara atau siklus yang tidak baik maka dari itu ruangan perlu ditata selain dari segi polusi udara juga dari segi siklus udara.

Faktor kedua yang memiliki pengaruh dominan terhadap efisiensi kerja karyawan adalah kesejahteraan karyawan. Pemberian program kesejahteraan karyawan dapat mendorong karyawan untuk lebih baik dan bersemangat, karena semangat kerja erat hubungannya dengan pemenuhan kebutuhan seseorang. Perusahaan yang telah memberikan kesejahteraan hidup yang layak bagi karyawannya, maka karyawan tidak berpikir lagi untuk mencari uang tambahan dari usaha yang lain, sehingga karyawan menjadi lebih fokus untuk bekerja, karena merasa hak-hak mereka sebagai karyawan sudah dipenuhi oleh perusahaan. 
Tingginya fokus karyawan dalam bekerja akan semakin meningkatkan efisiensi kerja karyawan dalam melaksanakan pekerjaannya.

Faktor ketiga yang dominan mempengaruhi efisiensi kerja karyawan adalah kemampuan fisik karyawan. Kemampuan fisik berhubungan dengan kemampuan karyawan dalam melaksanakan dan menyelesaikan tugas-tugas yang dibebankan kepadanya. Karyawan yang sehat jasmani dan rohani akan lebih cepat menyelsaikan suatu pekerjaan, sehingga karyawan perlu meningkatkan kemampuan fisiknya agar dapat menghadapi persoalan-persoalan kerja. Tingkat stres yang tinggi perlu dihadapi dengan fisik yang prima. Fisik yang prima diperlukan dalam menyelesaikan tugas-tugas yang menuntut stamina, kecekatan, kekuatan dan bakat-bakat sejenisnya.

\section{KESIMPULAN DAN SARAN}

\section{Kesimpulan}

a. Faktor yang paling dominan mempengaruhi efisiensi kerja karyawan pada PT. Petro Fajar Berlian, Medan adalah kondisi ruangan kerja dengan nilai korelasi sebesar 0,848 .

b. Faktor kedua yang memiliki pengaruh dominan terhadap efisiensi kerja karyawan adalah kesejahteraan karyawan dengan nilai korelasi 0,842 .

c. Faktor ketiga yang memiliki pengaruh dominan terhadap efisiensi kerja karyawan adalah kemampuan fisik karyawan dengan nilai korelasi 0,798 .

d. Dari hasil pengujian faktor dapat disimpulkan bahwa pada faktor 1 bernilai 0,502 ; faktor 2 bernilai 0,477 , faktor 3 bernilai 0,579 , faktor 4 bernilai 0,572 dan faktor 5 bernilai 0,399. Kelima faktor yang terbentuk sudah tepat karena mempunyai nilai korelasi yang cukup tinggi. Dengan demikian, antara faktor cenderung terjadi interkorelasi.

\section{Saran}

a. Sebaiknya perusahaan lebih memperhatikan kondisi ruangan kerja karyawan agar karyawan dapat bekerja dengan efisien. b. Perlu dilakukan perbaikan terhadap waktu jam kerja dan syarat kerja, karena indikator tersebut merupakan indikator yang memiliki skor terendah.

\section{E. DAFTAR PUSTAKA}

Gani, Achmad. 2009. Analisis Faktor-faktor yang Mempengaruhi Efisiensi Pegawai Kantor Pelayanan Pajak Bumi dan Bangunan Kota Makassar, Jurnal Aplikasi Manajemen Vol 7, No 1. Feberuary 2009.

Hasibuan, Malayu SP. 2005. Manajemen Sumber Daya Manusia. Edisi Revisi, Cetakan Ketujuh. Jakarta : Bumi Aksara.

Kuncoro, Mudrajad. 2003. Metode Riset Untuk Bisnis dan Ekonomi. Jakarta: Erlangga.

Mangkunegara, Anwar Prabu. 2005. Evaluasi Efisiensi SDM. Bandung: PT. Refika Aditama.

Mathis, Robert L. \& Jackson John H. 2002 Manajemen Sumber Daya Manusia. Buku 2, Jakarta: Salemba Empat.

Miraza, 2004. Manajemen Sumber Daya Manusia, Edisi pertama, Cetakan Pertama Jakarta: Bumi Aksara.

Mulyadi, 2007. Sistem Akuntansi. Jakarta : Salemba Empat.

Riani, Asri Laksmi. 2011. Budaya Organisasi. Edisi Pertama, Cetakan Pertama, Yogyakarta: Penerbit Graha Ilmu.

Santoso, Singgih dan Tjiptono Fandy. 2001 Riset Pemasaran: Konsep dan Aplikasi SPSS Jakarta:Alex Media Komputerindo.

Sedarmayanti. 2001. Sumber Daya Manusia dan Produktivitas Kerja. Mandar Maju, Jakarta.

Simanjuntak, Payaman. 2001. Manajemen Sumber Daya Manusia. Buku 2, Jakarta Salemba Empat.

Sutrisno, Edy, 2009. Manajemen Sumber Daya Manusia. Edisi Pertama, Cetakan Pertama, Jakarta: Kencana Prenada Media Group. 